Columbia Law School

Scholarship Archive

1990

\title{
"Carrot and Stick" Sentencing: Structuring Incentives for Organizational Defendants
}

John C. Coffee Jr.

Columbia Law School, jcoffee@law.columbia.edu

Follow this and additional works at: https://scholarship.law.columbia.edu/faculty_scholarship

Part of the Criminal Law Commons, Criminal Procedure Commons, and the Law Enforcement and Corrections Commons

\section{Recommended Citation}

John C. Coffee Jr., "Carrot and Stick" Sentencing: Structuring Incentives for Organizational Defendants, 3 FED. Sent'G ReP. 126 (1990).

Available at: https://scholarship.law.columbia.edu/faculty_scholarship/528

This Article is brought to you for free and open access by the Faculty Publications at Scholarship Archive. It has been accepted for inclusion in Faculty Scholarship by an authorized administrator of Scholarship Archive. For more information, please contact scholarshiparchive@law.columbia.edu. 


\section{"CARROT AND STICK" SENTENCING: STRUCTURING INCENTIVES FOR ORGANIZATIONAL DEFENDANTS}

\author{
John C. Coffee, Jr.*
}

The new "Draft Guidelines for Organizational Defendants" released by the U.S. Sentencing Commission on October 25, 1990, explicitly adopt a "'carrot and stick' approach" to sentencing. While the boldly instrumental use made of sentencing penalties and credits in these guidelines will trouble some, the larger question is whether the Commission's social engineering will work. Two issues stand out: First, is the Commission's carrot mightier than its stick? At first glance, this may seem a surprising question because the "stick" in the Commission's guidelines seemingly packs a Ruthian wallop: fines under the draft guidelines are based on a multiple of the greater of (a) the pecuniary gain to the defendant, (b) the pecuniary loss to victims, or (c) an amount from a fine table, scaled to reflect the seriousness of the offense, which table goes up to a maximum of $\$ 165,000,000$. $^{1}$ Thus, because the maximum multiplier is three, a fine of up to $\$ 495,000,000$ is authorized for the most serious offenses, and, in cases where a pecuniary gain or loss is readily calculable, even greater fines could be presumptively required.

Still, this "stick" may be illusory, because the Commission's "carrot" will often trivialize it. Under $\S 8 \mathrm{C} 1.2(\mathrm{e})$, the multiplier can range as high as three, but if certain mitigating factors are present, it can fall as low as 0.15 . The net result is extraordinary latitude. Assume for example that the base fine is $\$ 1,000,000$. The operation of the multiplier then permits the actual fine imposed to range from $\$ 3,000,000$ (i.e., a multiplier of three) to $\$ 150,000$ (a multiplier of 0.15). In short, at any given fine level, depending on the presence or absence of these mitigating factors, the maximum fine will normally be twenty times the minimum fine; thus, rather than curtailing historical sentencing variation, these guidelines may well increase the range of actual outcomes.

The second issue surrounding the Commission's use of incentives involves its possible confusion of ends and means. The introduction to the Commission's draft indicates that the proposed guidelines "seek to provide clear incentives for organizations to strengthen internal mechanisms for deterring, detecting, and reporting criminal conduct by their agents and employees by providing tough penalties when organizations fail to take such steps." Ultimately, the Commission's inventive structure seeks to reward compliance plans, internal monitoring, and the noninvolvement of senior management in the criminal

\footnotetext{
* Adolf A. Berle Professor of Law, Columbia University Law School.

Copyright John C. Coffee, Jr., 1990.
}

activity. These are means to an end-the reduction of crime-rather than ends in themselves. Although the relevance of these factors seems clear, the cost of achieving them in terms of the sentencing goal of general deterrence is not. The unknown variables are (1) the degree to which compliance plans and internal monitoring reduce criminal activity, (2) the ability of courts to distinguish legitimate, effective internal monitoring from cosmetic or half-hearted attempts, and (3) the impact on general deterrence of reducing fines to a nominal level if such structural controls and procedures are institutionalized. It is easy, of course, to conclude that prudence dictates moderation in the absence of perfect knowledge, but this comment will conclude with a more specific suggestion: there is a better way to evaluate the corporation's efforts at crime prevention than to judge them at the moment of sentencing. Specifically, mitigation credits should be awarded on a provisional basis, through the vehicle of a suspended sentence, so that they thus remain subject to forfeiture if the organization is involved in related civil or criminal offenses during a reasonable period of unsupervised probation.

\section{AN OVERVIEW OF THE COMMISSION'S PROPOSED MITIGATION CREDITS} Section 8 C2.1(e) of the Commission's proposed guidelines provides for reductions in the multiplier based on a "mitigation score." In addition, under $\S 8 C 2.1(d)(2)$, the Sentencing Commission has proposed that the "gross pecuniary loss" caused by the crime would not be considered in determining the base amount to be so multiplied if "the organization qualifies for the mitigating factor set forth in subsection (e)(2)(A)(ii)" (that is, the "effective program to prevent and detect violations of law."). ${ }^{2}$

As a practical matter, my judgment is that in the case of the large publicly held conglomerate, eight of the nine possible mitigation points will be awarded if the corporation's lawyers have done their job properly. ${ }^{3}$ The most frequently prosecuted organizational crimes at the federal level are antitrust violations, environmental offenses, and governmental procurement fraud. 4 Senior management in a conglomerate firm will rarely be implicated in these offenses, which are necessarily committed at a lower level of operational management. Hence, the normal multiplier under $\S 8 \mathrm{C} 2.1$ (c) will be between 0.35 to 0.55 .

In contrast, in the case of privately held firms, the multiplier is likely to be substantially higher because in such firms senior management is less separated from operational details and there may not be any inside general counsel who monitors governmental regulators (such as the Sentencing Commission) and responds to the incentives they create. Thus, fewer efforts at institutionalizing compliance plans are likely to have been made in advance of the crime's commission, and hence mitigation credit under subdivisions (e)(2)(A)(ii) or (a)(2)(B) of $\S 8 \mathrm{C} 2.1$ is less likely. Typically, only 1-3 points are likely to be 
earned by such firms, thus keeping the multiplier in the 1.40 to 2.40 range. This estimate raises a basic policy issue: Do we need greater deterrence in the case of the large public corporation or the small private one? In the abstract, the answer may not be clear. However, even at the level of a 1-2 multiplier, the Commission's guidelines are likely to result in bankruptcy for the typical privately held firm that commits a crime of intermediate severity. Thus, higher multipliers are realistically possible only in the case of the large publicly held firm, where they may be illusory under these proposals. In short the Commission's carrot is for the large public firm, while its stick is reserved for the small private firm.

\section{THE THEORY OF INCENTIVES AS APPLIED TO ORGANIZATIONAL DEFENDANTS}

On the conceptual level, the Commission's approach is vulnerable to a variety of criticisms: First, the case for a "carrot" is more doubtful theoretically than it first appears. If one wishes "to provide clear incentives for organizations to strengthen internal mechanisms for deterring crime," one should only need to raise penalties in order for the rational organization to recognize that its own self-interest lies in improving its internal monitoring. In theory, the organization should invest in additional monitoring up to the point where the marginal cost of further controls just equals the expected marginal benefit. In this light, a "carrot" in the form of reduced penalties for monitoring could weaken this incentive to invest in crime prevention to the extent that it reduces the discounted or expected penalty. In addition, a perverse incentive may arise to invest in cosmetic monitoring - that is, monitoring that has no real impact on employee behavior, but that looks good at sentencing if the corporation is ever convicted. Such monitoring expenditures could be rationally made much as an insurance premium is paid, not to prevent the occurrence of the threatened event, but to reduce the loss if it does occur. At worst, there is even a danger of the same "moral hazard" problem that characterizes insurance: once sufficient "cosmetic" monitoring has been engaged in to minimize the expected legal penalty, less need exists to engage in true "preventive" monitoring.

These arguments against any mitigation credit for internal monitoring systems are open to a counterargument: corporations do not commit crimes; people do. The only purpose of corporate criminal liability, it can plausibly be asserted, is to encourage monitoring of the individual agent or agents who actually commit the crime. No system of monitoring is foolproof, and thus some crime will still occur, particularly when the agent's incentives differ from those of the corporation. Hence, once the corporation has installed an adequate monitoring system, there is no need to impose on it socially wasteful penalties (which only flow through vicariously to shareholders and others), because the purpose of corporate criminal liability has already been served. In effect, the case for a mitigation credit is much the same as the economic arguments for the superiority of negligence liability to strict liability: namely, a negligence system provides effectively equivalent incentives for the corporation to take due care without making it an insurer for conduct it cannot avert. ${ }^{5}$

These rival positions boil down to a problematic empirical question: is corporate crime the product of "rogue employees" whose personal cost/benefit calculus leads them to commit crimes, even when it is not in the corporation's economic self-interest for such conduct to occur? Or, is corporate crime more the consequence of subtler organizational pressures which, while never overtly requiring illegal action, leave the middle level manager exposed to internal disciplines when he fails to cut corners or attempts to comply fully with expensive regulatory programs? If one believes that "rogue" employees are the cause of corporate crime, then the most that can be gained through corporate criminal liability is effective (but inevitably imperfect) monitoring of employees, and thus substantial mitigation credits make sense. If, however, one suspects that pressured employees, rather than rogue employees, commit what are today the most frequent corporate crimes-environmental offenses, antitrust violations, and government procurement fraud 6 - then monitoring alone cannot be the answer. Indeed, it is even plausible that an "effective" monitoring system (at least one sufficient to satisfy a sentencing court) could co-exist with intensive budgetary pressures within the organization to cut corners. In such a world, middle level managers might fear detection by the corporation's legal monitoring system, but they would also realize that financial monitoring for failure to meet profit and cost-cutting goals would be even more certain to result in their detection and dismissal. Trapped in such a "no-win" situation, managers might rationally respond to the more likely danger of ouster for "insufficient" performance than the more remote danger of criminal prosecution. If such a state of affairs is plausible, then a policy of virtually eliminating the corporate financial sanction simply because the corporation has installed an effective monitoring system aggravates, rather than alleviates, this problem.

\section{THE COMMISSION'S ALTERNATIVE PROPOSAL}

It is clear that not all the Commission's members agree with the approach set forth in the official draft of its guidelines. Under an alternative version of $\S 8 \mathrm{C} 2.1$ (e) that was also published in the draft proposal, the mitigation score is limited to eight points, and the multiplier will only be able to go below 0.55 in the rare case where the corporation turns itself in prior to any public disclosure or government investigation. The criteria for awarding mitigation credits are also substantially tighter under this alternative section. ${ }^{7}$

Read side by side, the official and the alternative draft differ in three principal respects: First, the alternative version does not give any credit simply 
because senior management was uninvolved in the crime. Thus, the substance of $\$ 8 C 2.1(e)(2)(B)$ of the official draft does not appear in the alternative draft. Second, while $\$ 8 C 2.1(\mathrm{e})(2)(\mathrm{D})$ of the official draft gives credit if the organization "accepted responsibility for the offense" prior to sentencing, the alternative draft awards credit for this easily manipulated factor only if the organization also commenced "an internal investigation into responsibility for the offense" and "commits to take appropriate disciplinary action" against those found responsible "including through negligent inattention."8 Third, the alternative draft treats the entire mitigation credit as forfeitable if the corporation commits another related violation (whether criminal or civil in character) during a period of unsupervised probation. ${ }^{9}$

The alternative draft is far more skeptical of cosmetics and less willing to place significant weight on easily stage-managed post-offense conduct. Thus, it does not reward separately the fact that senior management was not involved in the crime. The problem with such a credit is two-fold: First, this factor typically results in a double-counting of the effective compliance plan factor; ${ }^{10}$ and, second, it may establish exactly the wrong incentive structure. If sentencing credit is given largely for lack of knowledge on the part of senior management, ignorance is rewarded. Effectively, the corporations that benefit from such a credit are those that maintain what some organization theorists have termed a "structure of plausible deniability"11 — that is, one in which senior management typically focuses exclusively on strategic and financial management and leaves operational details to the divisional management. Under such a structure, it will be a rare event when senior management learns in advance of impending criminal behavior. ${ }^{12}$ Thus, the more sensible approach is that taken by the alternative draft, which rewards only the implementation of an effective compliance program and only when senior management or compliance officials were not involved.

The alternative draft also declines to reward the mere acceptance of responsibility by the corporation, unless the corporation conducts an internal investigation to determine responsibility within the firm. While "acceptance of responsibility" may seem an anthropomorphic fallacy when applied to a legal fiction, the requirement of a post-mortem investigation in the alternative draft gives meaningful content to this provision by addressing an important point that compliance programs do not necessarily cover. What if, for example, there are indications that senior management either knew, or recklessly ignored, indications that a criminal conspiracy was in progress? When E. F. Hutton was convicted in the mid1980 s for a check-kiting scheme that defrauded its banks, the trail of complicity led from branch managers well up into the executive suite. Yet, internal investigations at this level can be compromised by the fact that the watchdogs have been hired by those who are to be watched. Although the alternative draft is somewhat ambiguously phrased on this point, the optimal procedure would be for the sentencing court to approve the general structure of the internal investigation-i.e., what outside counsel would conduct it, what its scope would include, whether a formal report would be prepared and who would see it-before significant mitigation credit is awarded for undertaking such an investigation. In effect, the organization should be rewarded for cleaning house retroactively, not just for establishing a proactive compliance list. Such a credit responds directly to the "structure of plausible deniability" by holding those who fail to monitor responsible for the organization's liability.

Ultimately, any policy evaluation of the wisdom of placing substantial sentencing weight on compliance plans or other monitoring systems must recognize that courts are inevitably making decisions about the adequacy and good faith of such efforts based on imperfect information. The simplest way to judge the sufficiency and good faith of an organization's monitoring efforts and compliance plan is to observe its subsequent history under that plan. Thus, perhaps the most important difference between the official and alternative drafts is the latter's provision that the total amount of any mitigation credit be treated as a suspended sentence and the organization placed under a sentence of unsupervised probation under a probation condition that it not commit any related violation during the period of probation, typically three to five years..$^{13}$ Either a new criminal conviction or related civil violations should trigger a probation revocation hearing. At this hearing, the court would have substantial discretion to impose some, or all, of the suspended sentence, basically on the premise that the mitigation credit previously awarded was undeserved. At a stroke, this provision both gives the court an opportunity to learn if the compliance plan worked and also places a financial Sword of Damocles over the head of a convicted corporation for a limited period.

\section{CONCLUSION}

Incentives make sense and should be utilized at sentencing. Still, the end purpose of sentencing is to deter and prevent crime, not to force the implementation of particular monitoring and control strategies that are still of unproven efficacy and may be vulnerable to manipulation. When the multiplier goes as low as 0.15 , this approach subordinates the end of general deterrence to the debatable means of encouraging the development of internal monitoring systems. Finally, it is always a mistake to make a decision prematurely, and thus any mitigation credits awarded should remain subject to forfeiture through a probation revocation hearing.

\section{FOOTNOTES}

\footnotetext{
${ }^{1}$ The sentencing court is not required to use the pecuniary gain or loss as its base figure where the calculation "would unduly complicate or prolong the sentencing process." See
} 
$\$ 8 C 2.1(d)(l)$. However, regardless of the base amount used, the court is expected to require the disgorgement of any pecuniary gain not otherwise disgorged. See $\S 8 \mathrm{C} 2.1(\mathrm{f})$. Moreover, because the fine is not counted in determining whether the gain has been fully disgorged, the potential penalty in cases where there is a pecuniary gain could be as high as four times the gain (that is, disgorgement plus the trebled gain).

${ }^{2}$ Application Note 7 to $\S 8 \mathrm{C} 2.1$ defines the concept of an "effective program to prevent and detect violations of law." This definition is excellent, cannot seriously be faulted, and is probably the best aspect of the proposed guidelines. Whether sentencing courts will seriously monitor compliance with this standard is another question.

${ }^{3}$ Under subdivision (e)(2)(A)(ii) $\$ 8 C 2.1$., the organization gets three points for an "effective" compliance program, and, under subdivision (e)(2)(B), it receives an additional two points for the non-involvement of management officials in a "policy setting or legal compliance position" or who exercised "substantial authority." However, Application Note 7 to the commentary to this section indicates that: "An organization will not ordinarily qualify for the mitigating factor under subdivision (e)(2)(A)(ii) unless it also qualifies for the mitigation factor set forth in subdivision (e)(2)(B)." In effect, if one applies, then the other will also, for a total of five points. The criteria in subdivision (e)(2)(C) and (D) involve post-offense conduct and should be generally available. Indeed, in the case of subdivision (e)(2)(D), which rewards the acceptance of responsibility, Application Note 11 to the Commentary indicates that the corporation need not even plead guilty to receive it.

${ }^{4}$ See Cohen, Corporate Crime and Punishment: An Update on Sentencing Practice in the Federal Courts, 1988-1990 (paper delivered at George Mason University School of Law conference on "Sentencing the Corporation," October 1990). Professor Cohen finds that antitrust offenses accounted for 20-30\% of all corporate offenses; government fraud, 20-25\%; and environmental crimes, $10-15 \%$. None of these crimes result in direct personal benefit to the actor, as in contrast some securities law offenses do.

${ }^{5}$ Under both a strict liability and a negligence system of liability, defendants will take precautions up to the point where the expected legal liability is equal to the precaution or avoidance costs. See Posner, ECONOMIC ANALYSIS OF LAW (3rd ed. 1986) at \$6.5. The leading difference between negligence and strict liability is that victims will take more precautions and reduce their level of activity under a negligence system. This latter factor probably deserves somewhat less weight in the criminal law context when victims have less reason to know that they are at risk.

${ }^{6}$ See note 4 supra.

${ }^{7}$ Alternative $\$ 8 \mathrm{c} 2.1(\mathrm{E})$ :

(e)(1) The minimum and maximum fine multipliers are those specified in the table below corresponding to the applicable mitigation score as determined under subsection (e)(2).

\begin{tabular}{llr} 
Mitigation & Minimum & \multicolumn{1}{c}{ Maximum } \\
Score & Multiplier & Multiplier \\
0 & 2.00 & 3.00 \\
1 & 1.80 & 2.70 \\
2 & 1.60 & 2.40 \\
3 & 1.40 & 2.10 \\
4 & 1.15 & 1.80
\end{tabular}
5
6
0.95
0.75
0.55
0.35
1.50
1.15
0.85
8

(2) The mitigation score is determined by totaling the points specified for each of the applicable factors set out in subdivisions (A) through (C) below.

(A) If more than one applies, use the greatest:

(i) Add 4 points if the management of the organization voluntarily and promptly reported the offense to appropriate governmental authorities prior to public disclosure, the commencement of a government investigation, and the imminent threat of disclosure of the wrongdoing; or

(ii) add 2 points if the organization prior to the offense had, and after the offense continues to maintain, an effective program to prevent and detect violations of law, and no policy-setting or legal compliance official within the organization or other person who exercised substantial managerial authority in carrying out the policies of the organization had knowledge of the offense, or would have had such knowledge had such person performed his or her responsibilities as contemplated by the compliance plan; or

(iii) add 1 point if other factors suggest that an organization exercised due diligence to prevent and detect violations of law of a character reasonably similar to the instant offense.

(B) Add 2 points if the organization cooperated fully with the government's investigation of the offense.

(C) Add 2 points if the organization:

(i) in a timely manner, prior to the adjudication of guilt, accepted responsibility for the offense, and took prompt and reasonable steps to remedy the harm caused by the offense; and

(ii) commenced, prior to sentencing, an internal investigation into responsibility for the offense, pursuant to which it commits to take appropriate disciplinary action against officers, employees, or other agents found to have been responsible, including through negligent inattention, for the commission of the offense.

${ }^{8}$ See $\S 8 \mathrm{C} 2.1(\mathrm{e})(2)(\mathrm{C})$ of the alternative draft. This requirement should be similarly incorporated into the two point credit for cooperation with the government under $\S 8 \mathrm{C} 2.1(\mathrm{e})(2)(\mathrm{B})$ of the alternative draft. In both cases, "cooperation" and "acceptance of responsibility" should be similarly read to require an internal investigation and allocation of responsibility.

${ }^{9}$ See $\S 8 \mathrm{D} 1.1(\mathrm{a})(4)$ of the alternative draft.

${ }^{10}$ See note 3 supra.

"This phrase was coined by Professor Abraham Zalesnik of the Harvard Business School to describe how chief executive officers insulated themselves from responsibility.

${ }^{12}$ For a general discussion of the relationship between organizational structures and avoidance of responsibility for corporate crime, see Coffee, "No Soul to Damn, No Body to Kick": An Unscandalized Inquiry into the Problem of Corporate Punishment, 79 Mich. L. Rev. 386 (1981).

${ }^{13}$ My objectivity in making this assessment can be questioned because prior to the promulgation of this draft, I suggested this suspended sentence approach directly to the Commission. 